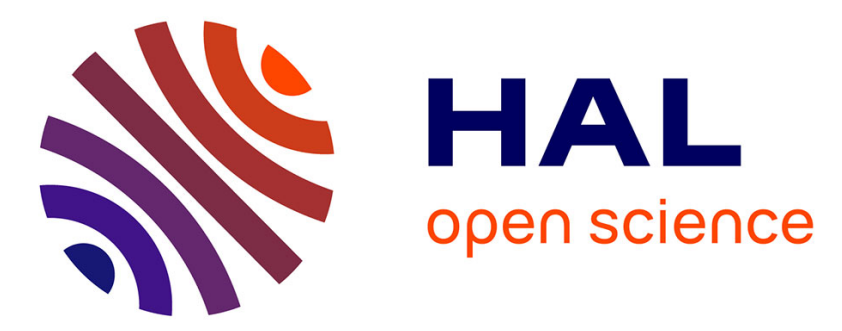

\title{
Campylobacter infection in adult patients with primary antibody deficiency
}

Jérémie Dion, Marion Malphettes, Lucie Benejat, Francis Megraud, Alain

Wargnier, David Boutboul, Lionel Galicier, Vincent Le Moing, Patrick

Giraud, Arnaud Jaccard, et al.

\section{To cite this version:}

Jérémie Dion, Marion Malphettes, Lucie Benejat, Francis Megraud, Alain Wargnier, et al.. Campylobacter infection in adult patients with primary antibody deficiency. Journal of Allergy and Clinical Immunology: In Practice, 2019, 7 (3), pp.1038-1041.e4. 10.1016/j.jaip.2018.06.014 . hal-02509193

\section{HAL Id: hal-02509193 \\ https://hal.science/hal-02509193}

Submitted on 22 Oct 2021

HAL is a multi-disciplinary open access archive for the deposit and dissemination of scientific research documents, whether they are published or not. The documents may come from teaching and research institutions in France or abroad, or from public or private research centers.
L'archive ouverte pluridisciplinaire HAL, est destinée au dépôt et à la diffusion de documents scientifiques de niveau recherche, publiés ou non, émanant des établissements d'enseignement et de recherche français ou étrangers, des laboratoires publics ou privés.

\section{(ㄷ)(1) $\$$}

Distributed under a Creative Commons Attribution - NonCommerciall 4.0 International 
1

2

4

5

6

7

8

9

\section{Campylobacter infection in adult patients with primary antibody deficiency}

Jérémie Dion ${ }^{1}, \mathrm{MD}$, Marion Malphettes ${ }^{1,2}, \mathrm{MD}$, Lucie Bénéjat ${ }^{3}$, MS, Francis Megraud ${ }^{3}, \mathrm{MD}$, Alain Wargnier ${ }^{4}, \mathrm{MD}, \mathrm{PhD}$, David Boutboul ${ }^{1}, \mathrm{MD}, \mathrm{PhD}$, Lionel Galicier ${ }^{1,5}, \mathrm{MD}$, Vincent Le

Moing $^{6}, \mathrm{MD}, \mathrm{PhD}$, Patrick Giraud ${ }^{7}, \mathrm{MD}$, Arnaud Jaccard ${ }^{8}, \mathrm{MD}, \mathrm{PhD}$, Raphaële NoveJosserand $^{9}, \mathrm{MD}$, Claire Fieschi ${ }^{1,2}, \mathrm{MD}, \mathrm{PhD}$, Eric Oksenhendler ${ }^{1,5}, \mathrm{MD}, \mathrm{PhD}$, and Laurence

Gérard $^{1,5}$, MD for the DEFI study group.

${ }^{1}$ Département d'Immunologie Clinique, Hôpital Saint-Louis, Assistance Publique-Hôpitaux de Paris, France.

${ }^{2}$ INSERM U1126, Centre Hayem, Hôpital Saint-Louis, Paris, France

${ }^{3}$ Centre National de Référence des Campylobacters et Hélicobacters, Laboratoire de Bactériologie, Université de Bordeaux, Bordeaux, France.

${ }^{4}$ Département de Microbiologie, Hôpital Saint-Louis, Assistance publique-Hôpitaux de Paris, France.

${ }^{5}$ EA3518, Université Paris VII Denis Diderot, Paris, France

${ }^{6}$ Département des Maladies Infectieuses et Tropicales, Centre Hospitalier Régional de Montpellier, France.

${ }^{7}$ Département de Néphrologie et Médecine Interne, Clinique du Pont de Chaume, Montauban, France.

${ }^{8}$ Département d'Hématologie Clinique, CHU de Limoges, France

${ }^{9}$ Département de Médecine Interne, Centre Hospitalier Lyon-Sud, Lyon, France

Corresponding author: Dr Laurence Gérard. Département d'Immunologie Clinique. Hôpital Saint-Louis. 1, avenue Claude Vellefaux. 75010 Paris. France.

Tel: 33(1) 42499177

Fax: 33(1) 42499472

Mail: laurence.gerard@aphp.fr

Funding. DEFI study was initially supported by public national program for clinical research (PHRC, INSERM RBM0333). The funding source had no role in the present ancillary study. 
35

36

37

2

Potential conflicts of interest. L.B. has received grants for her institution from Allergan, and support for travel/accomodations/meeting expenses from R-Biopharm and Mobidiag. F.M. has received grants from Allergan, and payment for lectures including service on speakers bureaus from Allergan and Takeda. L.Ga. has been consultant for Baxalta, has received payment for development of educational presentations from Amgen, Roche, Janssen Pharmaceuticals, GlaxoSmithKline, Pfizer, Raison et Santé, Baxalta, and support for travel/accomodations/meeting expenses from Janssen Pharmaceuticals, GlaxoSmithKline, and Shire. A.J. has received payment for lectures from Janssen Pharmaceuticals and Abbvie, travel/accomodations/meeting expenses from Janssen Pharmaceuticals, Celgen, Takeda, and Gilead Sciences. E.O. has received personal fees from CSL Behring, Shire, non financial support from Janssen Pharmaceuticals, has served on advisory boards for CSL Behring and Shire. L.Gé. has received support for travel/accomodations/meeting expenses from Janssen Pharmaceuticals and Gilead Sciences.

J.D., M.M., A.W., D.B., V.L.M., P.G., R.N.J.: no conflict

Word count: 987 


\section{Clinical implication Box}

54 In patients with severe primary antibody deficiency, Campylobacter infection is a major cause of

55 chronic or recurrent diarrhea. The frequent recurrence with different strains and the high frequency

56 of bacteremia suggest an increased susceptibility to this pathogen in this population.

57 


\section{To the editor:}

Primary antibody deficiency (PAD) is characterized by a defective immunoglobulin production and recurrent infections, mostly involving respiratory and gastrointestinal tracts.

Chronic or recurrent diarrhea is reported in up to $23 \%$ (1). Campylobacter infection is a common cause of infectious diarrhea, reported in 1.2 to $7.5 \%$ of patients with common variable immunodeficiency (CVID), the most frequent PAD (1-3). The aim of this study was to describe Campylobacter infection in patients with PAD included in a large nationwide study and analyze factors associated with susceptibility to this pathogen.

The DEFI (DEFicit Immunitaire) study is an ongoing large cross-sectional French multicentric study of adults with PAD, with retrospective collection of clinical data (2). All patients with a history of bacteriologically documented Campylobacter infection were identified, and clinical data were collected for each episode. Factors associated with recurrent infection were assessed as odds ratio (OR) and 95\% confidence interval (CI), calculated by means of simple regression analysis. In patients with available material, strains of each episode were characterized using molecular analysis and compared (Table E1A in the Online Repository). A comparison of immunodeficiency-related characteristics of patients with and without Campylobacter infection was performed in the homogenous group of CVID patients. The control group included CVID patients from DEFI centers who confirmed that patients did not develop Campylobacter infection after enrollment (Figure E1 in the Online Repository). After correction for multiple comparisons, a $\mathrm{P}<0.016$ was considered significant.

Since 2004, 790 patients with PAD were included in the DEFI study, and 51 presented with Campylobacter infection (6.5\%). Medical chart was available for review in 45 patients. Characteristics of these patients at the time of enrollment in DEFI are detailed in Table E2 in the Online Repository. A total of 97 episodes were recorded (Table 1). The overall 
distribution of Campylobacter species was unremarkable. Antimicrobial susceptibility testing revealed a higher resistance rate than in the general population for each antibiotic tested (See Figure E2 in the Online Repository). A comorbidity was present in 55\% of Campylobacter episodes, and a coinfection by other enteropathogens in 10\%. Most patients were receiving concomitant therapy at the time of episode. One patient with end-stage cirrhosis died with Campylobacter bacteremia. Overall, bacteremia was observed in 24 episodes (13 patients), and was associated with extra-intestinal complication in 10 episodes.

Nineteen patients (42\%) presented with recurrent (2 to 11) episodes. Factors associated with recurrent episodes were the presence of comorbidity (OR, 3.7 [95\%CI, 1.1-13.1]), and undetectable serum IgA (OR, 8.6 [95\%CI, 1.1-21.2]). None of these factors remain significant in multivariate analysis. Molecular study of a subset of 18 strains from five patients with recurrent infections demonstrated that all strains were different, even when the antimicrobial susceptibility testing was similar and when the episodes occurred closely over time (Table E1B in the Online Repository). Compared to 288 CVID patients without Campylobacter infection, CVID patients with Campylobacter infection presented a higher prevalence of consanguinity and a more severe CVID phenotype, with more frequent disease-related complications, lower serum immunoglobulin levels, lower B and NK cells, and a trend for lower naive CD4+T cell at the time of enrollment in the DEFI study (Table 2).

This study is the first description of a large series of patients with PAD and Campylobacter infection. The $6.5 \%$ prevalence was probably underestimated due to the retrospective nature of the clinical data collection. In this population symptoms were mostly restricted to an isolated, frequently severe, chronic watery diarrhea, with associated malnutrition, leading to repeated hospitalizations and impaired quality of life. Other digestive symptoms and fever were less frequent than those observed in the general population (4). In contrast, bacteremia as well as extra-digestive localizations were more frequent (25\% versus $0.15-2 \%$, and $22 \%$ 
107

versus 7\%, respectively) (5). Despite frequent hospitalizations, the overall prognosis was good. Recurrence rate was high (42\%) compared to $1.2 \%$ in the general population (6), and was associated with extra-intestinal comorbidity and undetectable $\operatorname{IgA}$ level in univariate analysis. Although limited by the number of available strains, molecular profile of strains from patients with recurrent infections were all different. Thus, we could hypothesize that reinfection is more likely than persistent colonization, although colonization with multiple strains cannot be excluded.

Conditions associated with the occurrence of Campylobacter infection were described in an analysis restricted to a large homogenous group of 325 CVID patients. The present data suggest that hypochlorydria, either PPI-induced or associated with autoimmune gastritis, might play an important role in the pathogenesis of this infection. Almost all CVID-associated complications, particularly liver and gastrointestinal disease, were more frequent in patients with Campylobacter infection. A more severe immune deficiency at CVID diagnosis, with lower serum immunoglobulin level was also observed. Even in patients with immunoglobulin replacement therapy, IgM and IgA levels remain very low. IgA and IgM, almost absent in immunoglobulin batches, are more important than $\operatorname{IgG}$ in Campylobacter immunity (7). B-cell and specifically switch memory B cell deficiency was also more severe in CVID patients with Campylobacter infection than in patients without. This is in line with the high prevalence of Campylobacter infection observed in Good syndrome and XLA, two conditions associated with no circulating B cells (Figure E1 in the Online Repository). B-cells are also known to be important for the dialogue between immune system and gut microbiota, whose composition is important for Campylobacter immunity (8). T-cells may also play an important role, with a trend for decreased naive T-cells. Indeed, fifteen patients (40\%) presented with a severe associated T-cell defect and could be considered as Late Onset Combined Immunodeficiency (data not shown) (9). 
132 In patients with PAD, Campylobacter infection is quite frequent and seems to be related to

133 various factors adding up together: severity of the immune deficiency, PAD complication, and

134 associated antibiotics, immunosuppressive therapies and PPI. It is characterized by a high

135 frequency of recurrence and bacteremia. Recurrence is associated with the presence of

136 comorbidity and $\operatorname{IgA}$ defect, and turned out to be due to reinfection more than to persistent

137 colonization, suggesting a specific susceptibility despite immunoglobulin substitution. 


\section{References}

1. Cunningham-Rundles C, Bodian C. Common Variable Immunodeficiency: Clinical and Immunological Features of 248 Patients. Clin Immunol 1999;92:34-48.

2. Oksenhendler E, Gérard L, Fieschi C, Malphettes M, Mouillot G, Jaussaud R, et al. Infections in 252 patients with common variable immunodeficiency. Clin Infect Dis 2008;46:1547-54.

3. Chapel H, Lucas M, Patel S, Lee M, Cunningham-Rundles C, Resnick E, et al. Confirmation and improvement of criteria for clinical phenotyping in common variable immunodeficiency disorders in replicate cohorts. J Allergy Clin Immunol. 2012 Nov;130(5):1197-1198.e9.

4. Peterson MC. Clinical aspects of Campylobacter jejuni infections in adults. West J Med. 1994 Aug;161(2):148-52.

5. Nielsen H, Hansen KK, Gradel KO, Kristensen B, Ejlertsen T, Østergaard C, et al. Bacteraemia as a result of Campylobacter species: a population-based study of epidemiology and clinical risk factors. Clin Microbiol Infect 2010 Jan;16(1):57-61.

6. Arsenault J, Ravel A, Michel P, Berke O, Gosselin P. Do patients with recurrent episodes of campylobacteriosis differ from those with a single disease event? BMC Public Health 2011;11:32.

7. Janssen R, Krogfelt KA, Cawthraw SA, van Pelt W, Wagenaar JA, Owen RJ. HostPathogen Interactions in Campylobacter Infections: the Host Perspective. Clin Microbiol Rev 2008;21:505-18.

8. Dicksved J, Ellström P, Engstrand L, Rautelin H. Susceptibility to Campylobacter infection is associated with the species composition of the human fecal microbiota. mBio 2014;5:e01212-4.

9. Bertinchamp R, Gérard L, Boutboul D, Malphettes M, Fieschi C, Oksenhendler E, et al. Exclusion of Patients with a Severe T-Cell Defect Improves the Definition of Common Variable Immunodeficiency. J Allergy Clin Immunol Pract 2016;4:1147-57. 
167 Table 1. Description of 97 Campylobacter episodes in 45 patients included in the DEFI study. 168 Results are expressed as median (IQR), or number/number of episode with available data (\%).

\begin{tabular}{|c|c|c|}
\hline Characteristics & No. or median & $\%$ or IQR \\
\hline \multicolumn{3}{|l|}{ Clinical features } \\
\hline Digestive symptoms & $81 / 87$ & 93 \\
\hline Diarrhea & 79 & 91 \\
\hline Chronic diarrhea & 39 & 45 \\
\hline Abdominal pain & 15 & 17 \\
\hline Vomiting & 3 & 3 \\
\hline Fever & $21 / 84$ & 25 \\
\hline Bacteremia & $24 / 97$ & 25 \\
\hline Extra-intestinal symptoms & $18 / 83$ & 22 \\
\hline Respiratory & 7 & 8 \\
\hline Osteo-articular & 5 & 6 \\
\hline Urinary & 2 & 2 \\
\hline Cutaneous & 5 & 6 \\
\hline Concomitant infection $^{\mathrm{a}}$ & $17 / 84$ & 20 \\
\hline Comorbidity $^{\mathbf{b}}$ & 53 & 55 \\
\hline \multicolumn{3}{|l|}{ Complications } \\
\hline Hospitalisation & $33 / 85$ & 39 \\
\hline Duration, days & 7 & $3-14$ \\
\hline Late complications $^{\mathbf{c}}$ & 9/97 & 9 \\
\hline \multicolumn{3}{|c|}{ Current therapy at Campylobacter diagnosis } \\
\hline Immunosuppressive drugs $^{\mathrm{d}}$ & $35 / 88$ & 40 \\
\hline Proton pump inhibitors & $41 / 81$ & 51 \\
\hline Ig replacement therapy & $79 / 90$ & 87 \\
\hline Antibiotic prophylaxis & $30 / 84$ & 35 \\
\hline Serum Ig levels, $g / L$ & $\mathrm{n}=37$ & \\
\hline $\operatorname{IgG}$ & 6.5 & 03-09 \\
\hline $\operatorname{Ig} \mathrm{A}$ & 0.05 & $0-0.3$ \\
\hline Undetectable IgA level & 31 & 83 \\
\hline $\operatorname{IgM}$ & 0.12 & $0.05-0.6$ \\
\hline Undetectable IgM level & 20 & 57 \\
\hline Campylobacter species & $\mathrm{n}=97$ & \\
\hline Campylobacter jejuni & 55 & 56 \\
\hline Campylobacter coli & 19 & 20 \\
\hline Other Campylobacter species & 4 & 4 \\
\hline Unspecified & 19 & 20 \\
\hline
\end{tabular}

169 Abbreviations: Ig, immunoglobulin; IQR, interquartile range.

$170{ }^{a}$ Digestive infection in 10 cases: Helicobacter pylori gastritis $(n=4)$, lambliasis $(n=2)$,

171 Clostridium difficile colitis $(\mathrm{n}=3)$, cytomegalovirus colitis $(\mathrm{n}=2)$; urinary infection in 4 cases;

172 respiratory infection in 3 cases. 
$173{ }^{\mathrm{b}}$ Diabetes ( $\mathrm{n}=2$ patients), chronic liver disease ( $\mathrm{n}=13$ patients), blood neoplasia ( $\mathrm{n}=3$

174 patients), or transplantation ( $\mathrm{n}=1$ patient).

$175{ }^{\mathrm{c}}$ Reactive arthritis ( $\left.\mathrm{n}=8\right)$, relapsing erythema nodosum $(\mathrm{n}=1)$.

$176{ }^{d}$ Prednisone $(n=9)$, budenoside $(n=18), T N F \alpha$ (tumor necrosis factor alpha)-blocker $(n=2)$,

177 methotrexate $(n=7)$, mycophenolate $(n=2)$. 
179 Table 2. Comparison between common variable immunodeficiency (CVID) patients with

180 Campylobacter infection (Campylo pos) and without Campylobacter infection (Campylo neg)

181 at enrollment in the DEFI study. Results are expressed as median (IQR) or number (\%).

182

\begin{tabular}{|c|c|c|c|}
\hline Characteristics & $\begin{array}{c}\text { Campylo pos } \\
(n=37)\end{array}$ & $\begin{array}{c}\text { Campylo neg } \\
(n=288) \\
\end{array}$ & $\mathbf{P}$ \\
\hline \multicolumn{4}{|l|}{ Population } \\
\hline Female & $22(59)$ & $172(58)$ & 0.98 \\
\hline Consanguinity & $10(27)$ & $27(10)$ & $0.002 *$ \\
\hline Age at CVID diagnosis & $32(25-44)$ & $37(26-50)$ & 0.17 \\
\hline \multicolumn{4}{|l|}{ Clinical complications } \\
\hline Infection only & $10(27)$ & $167(58)$ & $<10^{-3} *$ \\
\hline Disease-Related Complication $^{\mathrm{a}}$ & $27(73)$ & $104(36)$ & $<10^{-3} *$ \\
\hline Lymphoid proliferation & $20(54)$ & $75(26)$ & $<10^{-3} *$ \\
\hline Granulomatosis & $11(30)$ & $39(13)$ & $0.01 *$ \\
\hline Autoimmune cytopenia & $8(22)$ & $48(17)$ & 0.45 \\
\hline Opportunistic infection & $10(27)$ & $22(8)$ & $0.001 *$ \\
\hline Chronic liver disease $\mathrm{b}^{\mathrm{b}}$ & $15(40)$ & $42(15)$ & $<10^{-3} *$ \\
\hline Gastrointestinal complication & $31(84)$ & $117(41)$ & $<10^{-3} *$ \\
\hline Pernicious anemia & $5(13)$ & $4(1)$ & $0.001 *$ \\
\hline Villous atrophy & $8(22)$ & $15(5)$ & $0.002 *$ \\
\hline IBD & $4(11)$ & $11(4)$ & 0.07 \\
\hline Digestive granuloma & $3(8)$ & $6(2)$ & 0.07 \\
\hline Other GI tract infection ${ }^{c}$ & $16(43)$ & $43(15)$ & $<10^{-3} *$ \\
\hline Acute recurrent diarrhea & $12(32)$ & $27(9)$ & $0.01 *$ \\
\hline Chronic diarrhea & $23(62)$ & $56(19)$ & $<10^{-3} *$ \\
\hline \multicolumn{4}{|l|}{ Biology at CVID diagnosis } \\
\hline \multicolumn{4}{|l|}{ Serum Ig level, g/L } \\
\hline $\mathrm{IgG}$ & $1.7(0.84-2.8)$ & $3.0(1.3-4.3)$ & $0.005^{*}$ \\
\hline $\operatorname{Ig} \mathrm{A}$ & $0.07(0.06-0.32)$ & $0.25(0.07-0.46)$ & $0.008 *$ \\
\hline $\operatorname{IgM}$ & $0.19(0.06-0.42)$ & $0.22(0.11-0.50)$ & 0.05 \\
\hline \multicolumn{4}{|l|}{ Blood cell count } \\
\hline Hemoglobin level, g/dL & $13(11-14)$ & $14(13-15)$ & 0.44 \\
\hline Platelet count, $\times 10^{9} / \mathrm{L}$ & $202(109-274)$ & $209(167-260)$ & 0.16 \\
\hline Neutrophil count, $\times 10^{6} / \mathrm{L}$ & $4000(2850-5760)$ & $3700(2850-5470)$ & 0.60 \\
\hline Lymphocyte count, $\times 10^{6} / \mathrm{L}$ & $1406(662-1918)$ & $1371(1025-1866)$ & 0.44 \\
\hline $\mathrm{CD} 3+\mathrm{T}$ cells & $1107(563-1658)$ & $1063(789-1426)$ & 0.95 \\
\hline $\mathrm{CD} 4+$ & $555(305-743)$ & $561(398-833)$ & 0.35 \\
\hline Naive CD $4+{ }^{\mathrm{d}}$ & $63(16-213)$ & $125(48-271)$ & 0.02 \\
\hline CD19+ B cells & $51(13-149)$ & $101(49-173)$ & 0.03 \\
\hline$<1 \%$ & $9(25)$ & $26(9)$ & $0.008 *$ \\
\hline SMB cells ${ }^{\mathrm{e}}$ & $0.3(0.1-2.5)$ & $2.7(0.8-7.5)$ & $<10^{-3} *$ \\
\hline NK cells & $71(37-122)$ & $106(62-195)$ & $0.008 *$ \\
\hline
\end{tabular}


184 Abbreviations: CVID, common variable immunodeficiency; IBD, inflammatory bowel

185 disease; GI, gastrointestinal; Ig, immunoglobulin; SMB, switch memory B cells

$186 *$ Significant $\mathrm{P}$ value $(<0.016)$, after correction for multiple comparisons

$187{ }^{\mathrm{a}}$ Disease-Related Complication: lymphoid proliferation including granuloma, autoimmune

188 cytopenia or enteropathy with villous atrophy (3)

$189{ }^{\mathrm{b}}$ Chronic liver disease in patients with CVID and Campylobacter infections was portal

190 hypertension $(n=4)$, nodular regenerative hyperplasia $(n=3)$, granulomatosis $(n=6)$, lymphoid

191 hyperplasia $(n=5)$, cholangitis $(n=1)$ and other $(n=8)$

$192{ }^{\mathrm{c}}$ Excluding Campylobacter

$193{ }^{\mathrm{d}}$ Naive CD4+ T cells CD4+CD45RA+CCR7+

$194{ }^{\mathrm{e}}$ Switch memory B cells CD19+IgD-CD27+ 


\section{Figure E1.}

\begin{tabular}{|c|c|c|c|c|c|c|c|}
\hline \multirow{2}{*}{$\begin{array}{l}\text { Updated centers } \\
\qquad(n=17)\end{array}$} & \multicolumn{6}{|c|}{ DEFI Study: 790 PAD patients (47 centers) } & \\
\hline & \multirow{2}{*}{ CVID } & \multirow{2}{*}{$\begin{array}{l}\text { Good } \\
\text { syndrome }\end{array}$} & \multirow[t]{2}{*}{ XLA } & \multirow{2}{*}{$\begin{array}{l}\text { IgG } \\
\text { subclass-D }\end{array}$} & \multirow[t]{2}{*}{$\lg A-D$} & \multirow[t]{2}{*}{ other } & \\
\hline \multirow{3}{*}{$\begin{array}{l}\text { CVID patients } \\
\text { without } \\
\text { Campylobacter } \\
\text { infection }\end{array}$} & & & & & & & \\
\hline & 506 & 22 & 26 & 66 & 18 & 152 & \\
\hline & \multicolumn{6}{|c|}{ Patients with Campylobacter Infection $(n=51)$} & \\
\hline \multirow[t]{2}{*}{288} & 41 & 5 & 3 & 1 & 0 & $1^{\mathrm{a}}$ & \\
\hline & Patie & ts with Cam & $\begin{array}{l}\text { lobac } \\
1=45 \text {, }\end{array}$ & $\begin{array}{l}\text { r Infection a } \\
7 \text { episodes) }\end{array}$ & d comp & te data & \\
\hline & 37 & 4 & 3 & 1 & 0 & 0 & \multirow{3}{*}{$\begin{array}{c}\text { Descriptive } \\
\text { analysis }\end{array}$} \\
\hline$\downarrow$ & \multicolumn{6}{|c|}{$\begin{array}{l}\text { Patients with relapsing Campylobacter Infection } \\
\qquad(\mathrm{n}=\mathbf{1 9}, \mathbf{7 1} \text { episodes) }\end{array}$} & \\
\hline analysis & 16 & 2 & 1 & 0 & 0 & 0 & \\
\hline
\end{tabular}

Abbreviations: PAD, primary antibody deficiency; CVID, common variable immunodeficiency; XLA, X-linked agammablobulinemia, D, deficiency.

${ }^{a}$ Patient with CD40 ligand deficiency 
Figure E2.



Abbreviation: AMC : Amoxicillin-Clavulanate; TMP-SMX, trimetoprim-sulfametoxazol;

NA, not available. 